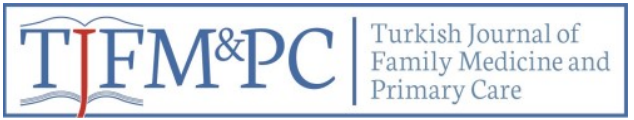

Original Research / Özgün araştırma

\title{
The Determination Of The Factors And Expectations Which Affect The Utilization of Health Services In Women: A Qualitative Research
}

\author{
Kadınlarda Sağlık Hizmetinden Yararlanmayı Etkileyen Neden ve Beklentilerin Belirlenmesi: Niteliksel Bir Araştırma

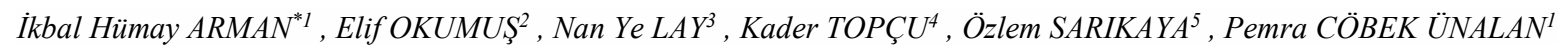

\section{ABSTRACT}

Aim: To determine the behaviors, expectations and experiences about health-sickness of women from society, to evaluate the socio-cultural characteristics of these behaviors. Method: This research is qualitative, planned as "case study". The research is sampled as goal-oriented maximum variation and 31 women included who are between 17-77 with different socio-cultural characteristics. Four focused interviews were conducted. Before the study, participants were informed and a questionnaire was used to question socio-demographic characteristics. The interviews were made at participants' houses. One interviewer and two observers was ready in each session. The voice recordings and observers' notes were trasncripted. No names have been transcribed. Each of the interviews were analyzed thematically, were commonised to reach research findings. Results: According to the analysis, there are five theme topics. 1. Physician (professionalism) characteristics affecting the choice of doctor (skills, attitude, gender, knowledge). 2. Expectations and behaviours about services related to women's health (afraid of the examination style, expectations of confidentiality and sympathy, prejudices). 3. Reasons for choosing health institutions (attitude of health workers, gender of doctor, hospital facilities, accessibility, prejudices, queue waiting). 4. Unmet health needs and thoughts about the causes (fear of malpractice, shyness, financial impossibilities, advanced appointments). 5. Attitudes on Family Health Centers (reasons for not using: lack of equipment, crowd, existing habits, doctor's attitude, distrust to doctor's knowledge). The participants repeated that dental health services are the most difficult to obtain. Conclusion: Socio-cultural characteristics, health services presentation and attitude of health workers influences expectations of individuals about utilization of health services. Therefore, when planning trainings of health workers, the applicants' health perceptions affected by the socio-cultural characteristics, learning methods which allows the development of a positive attitude and improves communication skills should be considered. Also, in the organization of health services, taking into account the factors affecting applicants' utilization of health services will be effective for the elimination the unmet needs.

Key Words: expectation, doctor, women, unmet, health care

\section{ÖZET}

Amaç: Bu çalışma, toplumumuzdaki kadınların sağlık ve hastalık davranışlarını, beklentilerini ve bu alanda yaşadıklarını ortaya koymayı ve bu davranışların sosyokültürel özelliklerini değerlendirmeyi amaçlamaktadır. Yöntem: Araştırmamız niteliksel tipte olup, "durum çalışmasıı" şeklinde planlanmıştır. Araştırmaya amaca yönelik maksimum çeşitlilik örneklemesi ile farklı sosyokültürel özelliklere sahip 17-77 yaş aralığındaki 31 kadın dahil edilmiştir. Çalışmada 7-8 kişilik dört odak grup görüşmesi gerçekleștirilmiştir. Çalışma öncesi katılımcılar bilgilendirilmiş, sosyo-demografik özellikleri sorgulayan bir anket uygulanmıștır. Görüşmeler katılımcıların bu amaç için toplandığı evlerde yapılıp, ses kayıt cihazı ile kayıt altına alınmış; kişi-yer isimleri kayıtlara geçmemiştir. Görüşmelerde bir görüşmeci, iki gözlemci hazır bulunmuştur. Her odak görüşme, kayıt ve gözlemci notları çözümlenerek tematik analiz edilmiş, kodlar üzerinde tartışılıp, ortaklaştırılarak bulgulara erişilmiştir. Bulgular: Ortaklaştırma sonrası ortaya çıkan 5 tema şöyledir: 1. Doktor seçimini etkileyen hekimlik (Profesyonellik) özellikleri (beceri, tutum, tavır, cinsiyet, bilgi). 2. Kadın sağlığı hizmetlerine özgü beklentiler ve davranışlar (muayene şeklinden çekinme, mahremiyet ve anlayış beklentisi, önyargı). 3. Sağlık kurumlarını tercih etme/etmeme nedenleri (sağlık personelinin tavrı, doktorun cinsiyeti, hastanenin imkânları, ulaşılabilirlik, önyargılar, sıra bekleme).

4. Karşılanamayan sağlık ihtiyaçları ve nedenlerine ait düşünceler (komplikasyon korkusu, utangaçlık, maddi olanaksızlık, ileri tarihli randevular). 5. Aile Sağlığı Merkezleri ile ilgili tutumlar (yararlanamama nedenleri olarak donanım eksikliği, kalabalık, var olan alışkanlık, doktorun tavrı, doktorun bilgisine güvensizlik). Katılımcıların ulaşmakta güçlük çektiği hizmetler içinde en sık tekrar eden ifade "diş sağlığı" olmuştur. Sonuç: Bireylerin sağlık hizmetlerinden yararlanmasını sosyokültürel özellikleri, sağlık hizmetlerinin sunum şekli ve sağlık çalışanlarının tutumu ile ilgili beklentileri etkilemektedir. Dolayısıyla sağlık çalışanlarının mesleki eğitimleri planlanırken başvuranların sağlık algısını etkileyen sosyokültürel özelliklerin dikkate alınması, iletişim becerilerini geliştiren ve olumlu tutum gelişimini sağlayan öğrenme yöntemlerinin kullanılması düşünülmelidir. Ayrıca sağlık hizmetlerinin örgütlenmesinde, başvuranların sağlık hizmetlerinden yararlanmasını etkileyen nedenlerin dikkate alınması karşılanmayan gereksinimlerin giderilmesi açısından etkili olacaktır.

Anahtar Kelimeler: beklenti, doktor, kadın, karşılanamayan, sağlı hizmeti

Received date / Geliş tarihi: 05.04.2019, Accepted date / Kabul tarihi: 12.09.2019

${ }^{1}$ Marmara Üniversitesi Tıp Fakültesi Aile Hekimliği Anabilim Dalı, İstanbul, TÜRKIYE.

${ }^{2}$ Kocaeli Üniversitesi Tıp Fakültesi Tıbbi Mikrobiyoloji Anabilim Dalı, Kocaeli, TÜRKIYE.

${ }^{3}$ İstanbul Arnavutköy Merkez Aile Sağlığı Merkezi, İstanbul, TÜRKIYYE.

${ }^{4}$ İstanbul Sağlık Müdürlüğü İl Ambulans Servisi, İstanbul, TÜRKIYE.

${ }^{5}$ Marmara Üniversitesi Tıp Fakültesi Tıp Eğitimi Anabilim Dalı, İstanbul, TÜRKIYE.

*Address for Correspondence / Yazışma Adresi: İkbal Hümay ARMAN, Marmara Üniversitesi Tıp Fakültesi Aile Hekimliği Anabilim Dalı, İstanbul, TÜRKIYE. E-mail: ikbalhumay@gmail.com

ARMAN Hİ, OKUMUŞ E, LAY YN, TOPÇU K, SARIKAYA Ö, CÖBEK ÜNALAN P. Kadınlarda Sağlık Hizmetinden Yararlanmayı Etkileyen Neden Ve Beklentilerin Belirlenmesi: Niteliksel Bir Araştırma. TJFMPC, 2020;14(1): 23-32.

DOI: $10.21763 / \mathrm{tjfmpc} .693036$ 


\section{GİRiş}

Bireylerin sağlıklı olmaları, sağlık algısı yani sağlık ve hastalığa gereken önemi vermeleri, sağlıklı davranışlar sergilemeleri, sağlık hizmetlerini gerektiği şekilde kullanmaları gibi bireysel alışkanlık, inanç ve beklentiler ile sağlık davranışlarına bağlıdır. Sağlık arama davranışı ise özellikle toplumsal düzeyde aile kültürü, ekonomik yapı, sağlık hizmetleri ile ilgili politikalar ve sağlık kurumlarının finansmanı gibi konularla yakından ilgilidir. Sağlık tutum ve davranışlarını ortaya koymaya yönelik araştırmalar; bireysel özellikleri ortaya koyarak, toplum sağlığının korunması, sürdürülmesi, yükseltilmesi ve sağlıkta eşitsizliklerin giderilmesinde bir araç olan sağlık politikalarına yön vermesi açısından son derece önemlidir. ${ }^{1}$ Sosyal, kültürel ve çevresel koşullar, sağlık algısını ve dolayısıyla sağlık hizmetlerine erişimi etkilemektedir. Bireylerin sağlık davranışları ve beklentileri de bu durumlara göre şekillenmektedir. Nitelikli bir sağlık hizmeti için hastaların beklentilerinin karşılanması temel öğelerden biridir.

Tıp ve sosyo-ekonomi alanında yapılmış pek çok çalışma ile hastaların nitelikli sağlık hizmeti tanımlamaları ve hastane seçiminde etkili olan çeşitli faktörler ortaya konmuştur. ${ }^{2}$ Hastane seçimi çok değişkenli bir durumdur. Hem sağlık hizmeti sağlayıcılarına ait özellikler (mülkiyet, boyut, kapasite, hizmet türü ve sayısı, hizmet durumu ve erişilebilirliği, akreditasyon, konum, performans ve itibar), hem de hizmet alanlarla ilgili faktörler (cinsiyet, yaş, 1rk, tıbbi durum, ödeme kaynakları ve bilgi) hastanın sağlık hizmeti tercihini etkiler. Bunları 10-P olarak toparlayan ve ürün/hizmet, yer, fiyat, fiziksel çevre, insanlar, süreçler, paket, performans, pozisyon, tanıtım olarak açıklayan Mosadeghrad, İran sağlık sistemini inceleyerek hizmet seçimine yönelik çok değişkenli bir tablo ortaya koymuştur. ${ }^{3}$

Kişiler somut ve soyut kaynaklardan sunulan bilgiler 1şığında zihinlerinde hastalık ve yaşamı tehdit eden durumlara ilişkin şemalar oluştururlar. $\mathrm{Bu}$ tutumlar sağlık davranışlarını da etkiler. "Algılanan sağlık", kişilerin kendilerini nasıl hissettiklerini göstermektedir. Kişinin kendi kendine sağlık düzeyini tanımlaması, kendinin biyolojik, ruhsal, toplumsal durumunu değerlendirmesine olanak sağlar. ${ }^{4}$ Sağlık ve hastalık algısı kişisel faktörlerden etkilenir. Kişisel özelliklerin yanı sıra ailesel, sosyal ve toplumsal ilişkiler; yaşam standartları, çalışma koşulları, sosyal, ekonomik ve çevresel koşullar, politikalar sağlığın belirleyicileri olarak sıralanan etmenler arasında yer almaktadır. ${ }^{5}$ Özetle; kişisel deneyimler, kronik hastalık durumu, bilgiler, önyargılar, gelenekler, değerler, sosyo-ekonomik düzey gibi faktörlerin sağlıklı yaşam biçimi davranışlarını etkilediği görülmektedir.

Günümüzde sağlık davranışını ve kişilerin sağlığı konusunda tercihlerini etkileyen faktörleri inceleyerek sağlık davranış modelleri ortaya atan pek çok yayın mevcuttur. Örneğin Sağlık İnanç Modelinin sağlığı korumak ve geliştirmek için, hastanın tedaviye uyumunu motive eden ya da engelleyen nedenleri açıklamada ve ölçmede etkin bir kılavuz olduğu söylenmektedir. ${ }^{6}$ İnsanların sağlıklı olmak için, sağlıklı yaşam algısı ve davranışlarını benimsemeleri ve bu davranışları hayat boyu uygulamaları gerekir. ${ }^{7}$

Dünya'daki ve Türkiye'deki veriler kadınların sağlı̆̆ının istenilen düzeyde olmadığını göstermektedir. Kadının toplumdaki yerinin temel bir konumda olmasından dolayı kadının sağlık durumu, bireyin kendisini ve çevresini büyük ölçüde etkilemektedir. Bu bağlamda kadın sağlığ1 ile ilgili araştırmalar yapılıp, kadınların konu hakkında bilinçlendirilmesi önemlidir. ${ }^{8}$ Kadınların sağlık haklarının sağlık bilgisine erişim, yeterli beslenme ve sağlı hizmetlerinden yararlanma hakkını da kapsadığı kabul edilmektedir. İnsan hakları açısından bakıldığında sağlık konusunda kadınların dezavantajlı olduğu durumlar hak ihlali olarak düşünülmektedir. Bunun en uç örneği ise anne ölümleridir. ${ }^{9}$

Son yıllarda yapılan çalışmalar kadın sağlığı konusunun önemini vurgulamıştır. Kadının sağlık durumu; çocukların, ailenin, toplumun ve çevrenin sağlık durumu ile doğrudan ilişkilidir. Kadının toplumsal konumu, genel sağlik düzeyinin iyileştirilmesi ve güçlendirilmesi, kadın sağlığına verilen önemle bağlantılıdır. ${ }^{10}$ Kadınların sağlığ1 geliştirme davranışlarını düşük düzeyde uyguladıkları yönünde bulgular mevcuttur. ${ }^{11}$ Kadınların sağlık davranışları konusunda bilgilendirilmeleri ve bu bilgilerini yaşama geçirebilmeleri için eğitim ile desteklenmeleri önerilmektedir. ${ }^{12}$

Birinci basamak sağlık hizmetleri, sağlık sisteminin giriş kapısı ve tıbbi yardım arayan insanların en kolay ulaşabileceği kurumlar olarak planlanmalıdır. Birinci basamak hizmetlerinin etkili bir şekilde verilmesi, toplumun hastalık yükünü azaltacağ1 için ikinci ve üçüncü basamak tedavi kuruluşlarında daha kaliteli sağlık hizmeti ve sağlık eğitimi verilmesine firsat tanıyacaktır. ${ }^{13}$ Diğer yandan Birinci basamak sağlık hizmetlerini kullananların çoğunluğunu kadınlar oluşturmaktadır. ${ }^{14,15}$ Dolayısıyla Birinci basamak sağlık hizmetleri planlanırken kadın sağlığı hizmetleri ile beraber bu alandaki karşılanamayan 
sağlık ihtiyaçlarının dikkate alınması önemlidir. Sağlık hizmetlerinin bu nitelikte planlanması yine de Birinci basamağın kullanılması için yeterli olmayabilir. Çünkü kişilerin Birinci basamağı kullanmalarını, burada sunulan hizmetlerden haberdar olmaları ve bu hizmetlere ihtiyaç duymaları etkileyecektir. $^{15,19}$

Araştırmanın amacı, toplumdaki kadınların sağlık ve hastalık ile ilgili ihtiyaç, beklenti, düşünce ve deneyimlerini ortaya koymak; bu alandaki davranışlarının sosyo-demografik ve kültürel özelliklerini değerlendirmektir. Böylece bireylerin kişisel ve yaşamsal özelliklerinin, sağlık ve hastalıkla ilgili bilgi, tutum ve davranışlarını ne şekilde etkilediğini tartışabilmek hedeflenmiştir. Araştırma sorusu; Kadınların sağlık hizmetlerinden yararlanmalarını etkileyen ihtiyaçları, beklentileri ve geçmiş deneyimleri nelerdir?.

$\mathrm{Bu}$ soru ile aşağıda belirtilen konularda kazanımlar hedeflenmiştir:

Kadınların;

*sağlık kuruluşu/doktor seçimini etkileyen düşüncelerini,

*sağlik hizmetlerinden

yararlanma/yararlanamama sebeplerini,

*sağlık hizmetlerinden beklentilerini,

*doktora sorulamayan/konuşulamayan durumlar1,

*Birinci Basamak kuruluşu olarak Aile Sağlık Merkezi'ne başvuru nedenleri ve ihtiyaçlarını, *Aile Sağlığı Merkezlerinden beklentilerini öğrenmektir.

\section{YÖNTEM}

Araştırmamız niteliksel tipte olup, niteliksel araştırma türlerinden "durum çalışması" tipinde planlanmıştır. $\mathrm{Bu}$ çalışmanın katılımcıları amaca yönelik maksimum çeşitlilik örneklemesi ile seçilmiş 17-77 yaş aralığında farklı sosyokültürel özelliklere sahip 31 kadından oluşmuştur.

Toplum hayatı içinde ve yukarıda sayılan ölçütlere uygun olan kadınlar arasından gelişigüzel olarak seçilenlerden izin alınarak kendi yaşam alanlarında veri toplanmıştır. Verileri odak grup görüşmeleri ile toplanan bu çalışmada görüşmeler katılımcıların toplandığ1 evlerde, yüz yüze yapılıp, ses kayıt cihazı ile kayıt altına alınmış; kişi ve yer ismi kayıtlara geçmemiştir. Çalışmada yapılandırılmış soru formu eşliğinde, 7 veya 8 kişilik dört adet odak grup görüşmesi gerçekleştirilmiştir. (Tablo 1). Çalışma öncesi katılımcılar araştırmanın konusu ve yöntemi hakkında bilgilendirilmiş, sosyo-demografik özellikleri sorgulayan 10 soruluk bir anket uygulanmıştır. Helsinki Bildirgesi'ne uygun şekilde aydınlatılmış onamları alınmış, kişilerin mahremiyetlerinin korunduğu görüşmeden evvel katılımcılara belirtilmiş, tek tek izinleri alınmıştır.

Görüşmelerde bir görüşmeci, iki gözlemci hazır bulunmuştur. Görüşmelerde 4 araştırmacı görüşmeci olarak görev almış ve bunların her biri araştırma öncesinde "niteliksel araştırmalarda odak grup görüşmesi nasıl yapılır?" konulu bir eğitime katılmışlardır. Her odak görüşmenin, ses kayıtları kayıtlardaki sözlü olmayan ifadeler de dikkate alınarak transkriptler haline getirilmiştir. Ses kayıtları, analizler ve raporda isim kullanılmamış, kişisel bilgiler korunmuş, odak gruplar, katılımcılar ve araştırma bulguları bu durumdan olumsuz etkilenmemiştir. Görüşme sırasında görüşmeci ve gözlemciler hiçbir yorum ve katkıda bulunmamıs, yalnız katılımcıları destekleyen bir atmosfer içerisinde konuşmaları sağlanmıştır.

Analiz; Gözlemci notları, sosyo-demografik özellikleri sorgulayan anket verileri transkriptlerle birlikte çözümlenmiştir. Dört araştırmacı her bir odak görüşme transkriptini bağımsız olarak değerlendirerek kod listeleri oluşturmuştur. Daha sonra kod listeleri üzerinde birçok kez tartışmalar yapılarak temaların seçiminde uzlaşmaya varılmıştır. Tematik içerik analizi yöntemiyle kodlar üzerinden 5 adet temaya ulaşılmıştır.

\section{BULGULAR}

Toplam 31 katılımcıdan 15'inin 40 yaş üzerinde ve 19'unun evli olduğu bu niteliksel çalışmada katılımcıların diğer özellikleri Tablo 2'de izlenebilir.

Dört araştırmacı tarafından bağımsız olarak yapılan kodlama sonrasında, tartışmalarla tematik analiz tamamlanmıştır. Ortaya çıkan ana temalar Tablo 3'de izlenebilir 
Tablo 1. Odak Grup Görüşme Soruları

\begin{tabular}{|l|l|}
\hline $\mathbf{1 a}$ & Sağlı problemlerinizde ilk nereye başvurursunuz? \\
\hline $\mathbf{1 b}$ & Neden burayı tercih edersiniz? \\
\hline $\mathbf{2}$ & Daha önce hangi konularda sağlık hizmetinden yararlandınız? \\
\hline $\mathbf{3 a}$ & İhtiyacınız olduğu halde yararlanamadı̆̆ınız sağlık hizmeti var mı? \\
\hline $\mathbf{3 b}$ & Var ise, hangi hizmetlerden yararlanamıyorsunuz? \\
\hline $\mathbf{3 c}$ & Var ise, sizce neden yararlanamıyorsunuz? \\
\hline $\mathbf{4 a}$ & Aile sağlık merkezlerinden sağlık hizmeti alıyor musunuz? \\
\hline $\mathbf{4 b}$ & Hizmet alıyorsanız, hangi hizmetler? \\
\hline $\mathbf{4 c}$ & Hizmet almıyorsanız, neden? \\
\hline $\mathbf{5}$ & Kadın sağlığı ile ilgili şikâyetlerinizde sağlık hizmetlerinden rahatlıkla yararlanabiliyor musunuz? \\
\hline $\mathbf{5 b}$ & Evet ise hangi durumlarda ve ne şekilde? \\
\hline $\mathbf{5 c}$ & Hayır ise neden yararlanamıorsunuz? \\
\hline $\mathbf{6}$ & Doktora hiçbir zaman söyleyemem dediğiniz hangi sorunlar aklınıza geliyor? \\
\hline $\mathbf{6 b}$ & Doktorla belli konularda konuşamama nedeniniz nedir? \\
\hline $\mathbf{7}$ & Genel olarak sağlık hizmetleriyle ilgili olarak belirtmek istediğiniz bir şey var mı? \\
\hline
\end{tabular}

Tablo 2. Katılımcıların Özellikleri $(n=31)$

\begin{tabular}{|c|c|c|}
\hline $\begin{array}{l}\text { YAŞ } \\
\text { (ortalama 38, ortanca 41, minimum 17, maksimum } \\
\text { 77) }\end{array}$ & $\begin{array}{l}\text { 17-24: } \\
\text { 25-40: } \\
\text { >40: }\end{array}$ & $\begin{array}{l}11 \\
5 \\
15\end{array}$ \\
\hline Medeni Durum & $\begin{array}{l}\text { Bekar: } \\
\text { Evli: } \\
\text { Dul: }\end{array}$ & $\begin{array}{l}10 \\
19 \\
2\end{array}$ \\
\hline Meslek & $\begin{array}{l}\text { Öğrenci: } \\
\text { Ev hanımı: } \\
\text { Çalışıyor: } \\
\end{array}$ & $\begin{array}{l}10 \\
18 \\
3 \\
\end{array}$ \\
\hline Eğitim Durumu & $\begin{array}{l}\text { Okuma-yazma bilmiyor: } \\
\text { İlkokul-Ortaokul: } \\
\text { Lise: } \\
\text { Lisans ve üstü: }\end{array}$ & $\begin{array}{l}0 \\
12 \\
6 \\
14\end{array}$ \\
\hline $\begin{array}{l}\text { Sosyal güvence } \\
\text { (Sosyal Güvenlik Kurumu-SGK-) }\end{array}$ & $\begin{array}{l}\text { VAR: } \\
\text { YOK: }\end{array}$ & $\begin{array}{l}29 \\
2\end{array}$ \\
\hline Gelir Durumu & $\begin{array}{l}\text { Kötü: } \\
\text { Orta: } \\
\text { İyi: }\end{array}$ & $\begin{array}{l}1 \\
7 \\
23\end{array}$ \\
\hline
\end{tabular}

Tablo 3. Kadınların Sağlık Hizmetlerinden Beklentileri, İhtiyaçları, Tutum ve Davranışları

\begin{tabular}{|l|l|}
\hline Tema 1 & Doktor seçimini etkileyen hekimlik (profesyonellik) özellikleri \\
\hline Tema 2 & Kadın sağlığı hizmetlerine özgü beklentiler ve davranışlar \\
\hline Tema 3 & Sağlık kurumlarını tercih etme/etmeme nedenleri \\
\hline Tema 4 & Karşılanamayan sağlık ihtiyaçları ve nedenlerine ait düşünceler \\
\hline Tema 5 & Aile Sağlığı Merkezleri ile ilgili tutumlar \\
\hline
\end{tabular}


TEMA 1. Doktor Seçimini Etkileyen Hekimlik (Profesyonellik) Özellikleri (beceri, tutum, tavir, cinsiyet, bilgi vb)

Katılımcılar doktor seçimini etkileyen en önemli özellikleri; doktorun cinsiyeti, gösterdiği ilgi, sıcaklık, güler yüz, olumlu iletişim becerileri, deontolojik yaklaşım, hastayı bilgilendirme ve yeterli tıbbi bilgi sahibi olmak șeklinde ifade ettiler.

“...doktorun tabi güler yüzlü olması, dinlemesi insanı çok rahatlatıyor.” (48y, Evli, Ev hanimi)

“...özel mesela ilgi bekliyoruz. Yani doktorlar o kadar ağır vakalar ile karşılaşıyorlar ki devlette, senin orada anlattı̆̆ın problemler sanki biraz basit kaçıyor, tamam çok önemli değil falan deyip, çok fazla ilgilenmiyor." (42y, Evli, Ev hanımı)

"...hata olabilir, her meslek riskli, yani sizde... Ama sakın güler yüzlülüğünüzü kaybetmeyin., (47y, Evli, Ev hanımı)

“...Onun verdiği ilacı öbür doktor beğenmedi. Ben buna nasıl güveneyim. Çok güvenemediğim için ikisininkini de bıraktım..." (52y, Evli, Ev hanımı)

"Yani hasta gittiği zaman en iyi doktor da olsa en iyi hastane de olsa, ilk önce ilgiden iyileşiyor. Illgi görürse slcaklık görürse dediğini daha iyi anlatabiliyor" (43y, Evli, Ev hanım1)

“...benim o önyargımı kırdı o çatal olayı çok bunaltıyo sıkıntıya sokuyordu. Çok nazik davrand ç̧ok kibar davrandı..." (28y, Evli, Yazar)

“...doktorun ses tonu çok önemli...” (21y, Bekâr, Öğrenci)

"Ben ilk defa çatala çıktı̆̆ım zaman dedim ki anlat bana ne yapayım. Ilk defa karşılaşlyorum. Muayene yaparak bilgi veriyor. Yani konuşarak geçiyordu. Derin bir nefes al, sadece biraz soğuk olabilir diye. Çok iyi bir doktor." (24y, Evli, Ev hanımı)

"Hepsi aynı mı bilmiyorum ama bizim şeyimiz sanki biraz daha bilgisiz gibi geliyor bana" (49y, Evli, Ev hanımı)

“...tavsiye ettim. E çünkü bana teşhisi koydu...” (49y, Evli, Anaokulu öğretmeni)

"Doktor bana çok yanlış yaptı. Çok üzülmüştüm o zaman. Sizin yaptığınız hırsızlık dedi bana resmen. Çok zor. Çok ă̆rıma gitmişti. Büyüğünüze de biraz saygı bekliyor insan" (54y, Evli, Ev hanımı)

“...Değerden de çok insanlık katıcaksınız. Biz onu istiyoruz. Zaten eğitimi allyorsunuz, bizim sizden istediğimiz, doktorlardan, insanlı..." (49y, Evli, Ev hanımı)
TEMA 2. Kadın Sağlığı Hizmetlerine Özgü Beklentiler ve Davranışlar

Katılımcıların çoğu kadın sağlığı ile ilgili şikâyetlerinde doktora gitmekten çekinmekte, hatta utanmakta, doktorunu seçememekten ve muayene şeklinden rahatsızlığını dile getirmekte, gidenlerin tercihi de kadın doktor olmaktadır. "Orası ăgzım burnum değil ki öyle hop açayım!" ifadesini vurgulamak ve tüm katılımcıların mahremiyetle ilgili bu konuyu sorun olarak dile getirdiğini belirtmek gerekir. Doktorlardan beklenen; kadınlar için özel ve hassas olan bölgeler ile ilgili muayenelerde daha sevecen, duyarlı davranması, aralarındaki iletişimi iyileştirmesi ve karşılıklı empati kurulmaya çalışmasıdır.

“...Ben rahat edemiyorum, huzursuzum ben erkeğe nasıl açayım...” (41y, Evli, Ev hanımı)

“...Hani kendi eşinden başkasına kimseye bir şeyini görünemezsin, gösteremezsin...” (46y, Evli, Ev hanımı)

“...kanamanın geçmesini bekledim tabi. Çünkü özel bir bölge...” (29y, Evli, Mimar)

“...kadın doğum çok mahrem bir olay, çok güvenmen lazım ona...” (37y, Evli, Ev hanımı)

“...Utanlyorum. Bir kere spiral koydurmaya gittim bana dediler ki bir ay sonra kontrole gel... Gitmedim. Kadın olmasına răgmen gidemedim..." (42y, Evli, Ev hanımı)

"...orası ă̆zım değil ki öyle kolay açayım..." (44y, Evli, Ev hanımı)

"...aç bakalım, doktora normal geliyor belki ama böyle değil yani, ben de ötelerim...” (28y, Evli, Yazar)

“...Dinimizin temel esaslarına göre yani dinimizde namahremiyet var..." (77y, Evli, Ev hanımı)

“...şöyle bir sorun var devlet hastanelerinde mesela doktor Nalan bilmem ne... Mesela o oluyo da onun asistanı oluyo bi de bakıyorsunuz pat Cem Bey çıkıyo..." (44y, Evli, Ressam)

“...yani devlet hastanelerinde kadın doktor seçme hakkın yok. Yani bunu bilerek gitmen, o psikolojiye katlanman lazım..." (47y, Evli, Ev hanımı)

“...çatala çıkarıyorlar...” (43y, Evli, Ev hanımı)

“...Ve muayene pozisyonu beni sikıntıya sokacak tarzda olabileceği için şu anda sıkıntı yaşıyorum..." (24y, Evli, Ev hanımı)

“...Öyle bir problemim olmadı̆̆ için...” (37y, Evli, Ev hanımı)

“...Evli olsaydım daha rahat giderdim diye düşünüyorum...” (21y, Bekâr, Öğrenci) 
TEMA 3. Sağlık Kurumlarını Tercih Etme/Etmeme Nedenleri (sağlık personelinin tavrı, doktorun cinsiyeti, hastanenin imkânları, ulaşılabilirlik, önyargılar, sıra bekleme)

Katılımcılar, daha çok özeli tercih etme nedenlerini sıralarken, sağlık personelinin tavrının, doktor seçebilme hakkının ve hastane imkanlarının önemini vurguladılar. Ayrıca bazı katılımciların devlet hastanelerine ve Aile Sağlığı Merkezlerine yönelik önyargıları olduğu gözlendi.

“... Hastalı̆̆ım kendi çapımda kendi gözümde ĕger çok önemliyse güven alabileceğim böyle bana daha nazik davranılacă̆ı, ondan özel hastaneye gidiyorum..." (40y, Evli, Ev hanımı)

“... Büyük ihtimal sağllk problemleri tam olarak ortaya çıkana kadar gitmem...” (21y, Bekâr, Öğrenci)

“...aldĭ̆ımız hizmet. Yani işte siz mesela, tek kişilik bir odada kalmak istiyorsunuz. Hemşireniz gelsin size bakımını yapsın vs istiyorsunuz." (26y, Bekâr, öğrenci)

"Devlete gidemiyorum, çok kalabalık. Stra falan onları biz bekleyemeyiz. Yani vakit hızl olmall, çabuk, işim hemen görülmeli." (40y, Evli, Ev hanımı)

“...Küçük bir şeyse, mesela ateşi falan çıktı ben kendim hallederim, doktor benden fazla mı biliyor..." (42y, Evli, Ev hanımı)

"...Yani ilk olarak sağlık ocaklarına gidiyorum. Maddi olarak benim cebimi hiç sarsmıyor... "(43y, Evli, Ev hanımı)

“...sigortamız olduğu için gidiyoruz..." (24y, Bekâr, Öğrenci)

“...SSK'mız geçiyor bu çok önemli. Alınan fark ücretleri de oldukça uygun. Çok fazla bir fark ücreti alınmıyor..." (48y, Evli, Ev hanımı)

“...Hijyen şartları bi de çok sihhatli gelmedi." (44y, Evli, Ressam)

"...Oraya gitmenin sebebi ulaşmak kolay, yakın olduğu için, tabî̀ ki...” (46y, Evli, Ev hanımı)

“...çok bekliyoruz, çok uzun süreye randevu veriyorlar...” (54y, Dul, Ev hanımı)

"...hiçbir tecrübem yok. Ama bir önyargım var açıkçası. O yüzden gitmem...” (22y, Bekâr, Öğrenci)

“...Bizim zamanımızda öyle değildi, çıkarın donları derlerdi, biz de çıkarırdık...” (56y, Dul, Ev hanımı)

“... Bu biraz aile alışkanliğı. Yani hiç gitmediğimiz için. Babamın bir lafi vardı. Yıllardır babam SSK primi öderdi. Bari çocuklar bir şöyle gezmeye gidin derdi." (40y, Evli, Ev hanımı)

"İyi doktorlar gittiği için özelde de, bu ara bazı sıkıntılar için özele gitmeye başladım. Ihtiyaç hissetim. Ama iyi doktorların geldiğini görürsem yine de devlete dönmeyi tercih ederim." (52y, Evli, Ev hanımı)

“...çok bekliyoruz, çok uzun süreye randevu veriyorlar.” (22y, Bekâr, Öğrenci)

“...̈̈zellikle hemşirelerden çok rahatsızım. Birincisi hiçbir şekilde güleryüz yok, bitse de gitsek gibi baklyorlar..." (42y, Evli, Ev hanımı)

\section{TEMA 4. Karşılanamayan Sağlık İhtiyaçları ve Nedenlerine Ait Düşünceler}

İhtiyaç duyulduğu halde, karşılanamayan sağlı hizmetlerinin bulunduğu tespit edilmiştir. Bunlar başta diş hastalıkları ve psikolojik destek olmak üzere, çocuk ve iç hastalıkları yan dallarıdır. Sağlık hizmetine ulaşamama nedenleri olarak; bazı bölümlerin devlet hastanesinde olmaması veya çok yoğun olup sira gelmemesi sayılabilir. Ama bu alt yapı eksiklikleri yanında katılımcıların yanlış/eksik hekimlik uygulamalarına maruz kalma korkusu, kalabalık, sıra gelmemesi, toplumun etiketlemesi ve önyargılarından çekinmek gibi kaygılar sebebiyle de sağlık hizmetine başvuruların ertelendiği görülmüştür.

“...ilaç vererek film çekiyorlar. Gidemiyorum şimdi o korkuyla. Çok tehlikeliymiş...” (42y, Evli, Ev hanımı)

“...radyasyon yaylyor, kanser riski var diyorlar..." (46y, Evli, Ev hanımı)

“...doktor daha iyi bilir... Ama sonra anladık doktorların iyi bilmediğini... ne kazalar oluyor, yine gazetede çocuğa yanlış bir ĭgne, sinir damarına gelmiş, şimdi kolu yok..." (48y, Evli, Ev hanımı)

“...İ̈neden bir yakınım öldü...” (41y, Evli, Ev hanımı)

“...Hastanelerin çok yoğun olmasından kaynaklanan...” (21y, Bekâr, Öğrenci)

“...o kadar sıra oluyo ki bütün çocuklar o kadar hasta olmalarına răgmen orda sıkıntı çekiyorlar...” (28y, Evli, Yazar)

"...film çekmek gerektiğini söylediler. ... Hastanesindeki için 3 aya sıra veriyorlardı..." (22y, Bekâr, Öğrenci)

“...Gittim devlet hastanesine de gittim, $10 \mathrm{dk}$. bi baklyor. Seni böyle bir sandalyeye oturtuyor oğlumu götürtmüştüm. $10 \mathrm{dk}$. konuşuyor, oğlum konuşmak istemiyorum dedi. Nasıl bir muamele gördüyse artık..." (56y, Dul, Ev hanımı)

“...Özel hastanelerde ise bir gün için ... TL istiyorlardl. Ben de o yüzden çok geç kaldım..." (52y, Evli, Ev hanımı)

“...Tabii bir de psikolojik hastalıklar var yani depresyon panik atak gibi.. Bunlar da söylenmez kolay kolay. Kolay kabullenilemez, 
ben deli miyim gibi. Yani ben de olsam kabul edemezdim..." (24y, Bekar, Öğrenci)

“...çocuklarım antidepresan al falan diyorlar ama hakikaten düşününce acaba mı diyorsun, yine de kendine yediremiyorsun." (49y, Evli, Ev hanımı)

TEMA 5. Aile Sağlığı Merkezleri ile İlgili Tutumlar

ASM'ler ile ilgili sorulara verilen cevapların daha çok başvurmama nedenleri hakkında olduğu görülmüştür. Buralarda sunulan hizmetlerin yeterliliğine güvenmeme ve ekipman azlığı vurgulanmaktadır.

"...Yani ilaca gidiyorum. Muayene olmak için gitmiyorum." (37y, Evli, Ev hanımı)

“...bizim orada sağlık ocaklarında daha iyi bakım oluyor...” (24y, Evli, Ev hanımı)

"Ben güven duyamadığım için özel hastaneleri daha çok tercih ediyorum...” (47y, Evli, Ev hanım1)

"Bizim aile hekimimizin bilgisiz olduğunu düşünüyorum” (23y, Bekar, Öğrenci)

"Bir keresinde şişkinlik var dedim ilgilenmiyorlar bile. Beğenmiyorum yani..." (42y, Evli, Ev hanımı)

“...sağlık ocă̆ında mezura bulmak için oda oda dolaştıklarını hatırlıyorum. Çocuk var mezura yok...” (28y, Evli, Yazar)

“...kulak burun boğazdaki bakllan aletten dolayl orayl tercih ediyorum. $O$ aletle bakıldı ̆̆ında sinüzit filmine gerek kalmıyor. Ileri teknolojiden dolays KBB'ye özele gidiyorum..." (41y, Evli, Ev hanımı)

"Sağlık ocaklarl ile ilgili, henüz oturmamış..." (21y, Bekar, Öğrenci)

"Bana ilaç yaz diyorum yazmıyor." (43y, Evli, Ev hanımı)

"Ya gidiyorsun da, seni hiç muayene eden yok ki, soruyor ilaç mı yazıcam teyze” (56y, Dul, Ev hanım1)

"Bazen güvensizliklerle karşılaşıyoruz yani." (24y, Bekar, Öğrenci)

"Ya să̆lık ocă̆l doktoruna güvenmiyoruz. Hepsi aynı mı bilmiyorum ama bizim şeyimiz sanki biraz daha bilgisiz gibi geliyor bana, Ilaç yazdircam mesela ben on tane istiyosam hiç sormadan niye diye, veriyor hepsini. Rapor da istesem veriyor ilaç da istesem veriyor." (44y, Evli, Ev hanımı)

"Ama şu an să̆lık ocă̆ına gitme amacım da grip, soğuk algınlı̆̆l ya da basit bir boğaz ağrislysa gidiyorum yoksa daha yoğun bir hastalığım varsa daha koyu bir ağrlysa falan să̆llk ocă̆lyla uğraşmadan direk devlet hastanesi” (49y, Evli, Anaokulu öğretmeni)

\section{TARTIŞMA}

Araştırma bulgularımız; literatüre baktığımızda bulduğumuz niteliksel araştırma sayısı sınırlı olmakla birlikte sağlık algısı ve alınan hizmetlerin özelliklerine dair niteliksel ve niceliksel araştırmalar ile karşılaştırılmıştır.

Süleyman Demirel Üniversitesi tarafindan Burdur'da 382 kişi ile yapılan tanımlayıcı, topluma dayalı bir araştırmada kadınların \% 92,9'u kadın doktoru tercih etmektedir. ${ }^{16}$ Bizim araştırmamızda da buna benzer şekilde katılımcıların tamamı, özellikle kadın hastalıkları ile ilgili başvurularında mahremiyetten dolayı kadın doktor tercih ettiklerini dile getirmişlerdir. Aynı çalışmada katılımcıların \%59.9'u doktor seçiminde dikkat ettiği en önemli kriterin doktorun uzmanlık alanında kendini kanıtlamış olması olduğunu belirtmiştir. Bunu sırasıyla, detaylı bilgi vermesi, tanıdık olması, tavsiye edilmiş olması izlemiştir. Bizim araştırmamızda doktor seçiminde en önemli faktörün doktorun davranışları olduğu belirtilmiştir. Detaylı bilgi vermesi, bilgili olmas1, önceki olumlu deneyim, tavsiye edilmiş olması da doktor seçiminde etkili bulunmuştur. Birleşik Arap Emirliklerinde, doktor seçimini etkileyen kriterleri araştıran bir çalışmada kadın hastalıkları ve doğum için katılımcıların çoğu kadın doktor tercih edeceğini bunun nedeni olarak da mahremiyet, danışmanlık, dini inançları gereği ve kültürel gelenekler gereği olduğunu söylemiştir. Ayrıca doktorlar arasında tercih yaparken doktorun tavrının ve karakterinin önemli olduğunu vurgulamışlardır. ${ }^{17}$ Bizim araştırmamızda da, katılımcılar özellikle kadın hastalıkları ve doğum doktoru olarak kadın doktorları tercih etme nedenlerini mahremiyet, utanma, muayene şekli, doktorun tavrı olarak sıralamışlardır.

Araştırmamızda katılımcıların sağlık personelinden beklentilerini sorduğumuzda; doktorun ve sağlık personelinin tavrının hastaya karşı iyi olması gerektiği, özel ve hassas olan muayenelerde daha sevecen davranması isteği sıkça dile getirilen bir talep idi. Ankara'da yapılan 'Yeni doğum yapmış kadınların empatik iletişim beklentilerinin ebe/hemşireler tarafından karşılanma durumu' adlı araştırmaya katılan kadınların yarıya yakını ebe / hemşirelere güven duyduklarını ve sorunlarını paylaşabildiklerini belirtmişlerdir. Ebe/hemşirelerden beklentilerin daha çok "azarlanmamak" ve "güler yüzlü olmak" yönünde olduğu vurgulanmıştır. ${ }^{18}$ 
Konya'da hastane tabanlı yapılan bir çalışmada hastaların bir sağlık kurumunu tercih etmelerinde öne çıkan nedenler: Sosyal güvenlik kurumu anlaşmasının olması, çevre (eş, dost, akraba) tavsiyesi, önceki hastaların tavsiyesi, hastanedeki doktorların bilinirliği, doktorların tavsiyesi, hastanenin teknolojik altyapısının yeterliliği, hastaneye duyulan güven olarak sıralanmıştır. ${ }^{19}$ Bizim araştırmamızda da benzerlikler görülmektedir. Ancak bu araştırmada farklı olarak sıra beklemek ve önyargılar da katılımcılarımızın sıkça bahsettiği nedenler arasındadır. İran'da hastane seçim kriterlerini etkileyen faktörleri araştıran niteliksel bir çalışmada, hizmet tipi, hastane (eğitim araştırma veya devlet), tavsiye, maliyet, hastanın sağlık sigortası durumu, kolay erişim, fiziksel ortam, imkanlar, sağlık personelinin uzmanlığı (beceri ve deneyim), sağlık personelinin kişilerarası davranışları (nezaket) ve hastane itibarı olmak üzere 11 faktör önemli bulunmuştur. ${ }^{6}$ Hindistan'da yapılan başka bir çalışmada sağlık kurumu seçimini etkileyen temel faktörün doktorların becerisi olduğu gösterilmiştir. Hastaların çoğunluğu, mevcut imkânların yanı sıra doktorların ve diğer sağlık çalışanlarının davranışlarından memnun kalmıştır. Sunulan sağlık hizmeti, sürekli olarak ölçülüp, küçük değişiklikler yapılarak, bireysel süreçler ve temel altyap1 iyileştirilebileceği öngörülmüştür. ${ }^{20}$ Bizim araştırmamızda da devlet hastaneleri yerine özel hastaneleri tercih eden katılımcıların özellikle belirttiği faktörler benzerlik göstermektedir. Ayrica doktor seçimini etkileyen personel tutumlarının, hastane personelini tanıma veya onlardan memnunluk, geçmiş deneyim gibi kriterlerin, bizim araştırmamızda da ifade edildiği görülmüştür.

"Bir Sağlık Ocağına Kayıtlı 40-59 Yaş Grubu Kadınların Menopoz Yakınmaları ve Sağlık Kuruluşlarından Yararlanma Durumları" hakkında yapılan bir araştırmada, karşılanamayan sağlık hizmetlerinin nedenleri arasında; ihmal ve gereksiz görme, maddi durum yetersizliği, çok sıra bekleme, hastane ortamından memnuniyetsizlik sayılmıştır. ${ }^{21}$ Bizim araştırmamızda bu durum bazı bölümlerin devlet hastanesinde olmaması veya çok yoğun olup sıra gelmemesi şeklinde sayılabilir. Ayrıca yine benzer olarak katılımcıların yanlış/eksik hekimlik uygulamalarına maruz kalma korkusu, kalabalık, sira gelmemesi, toplumun etiketlemesi ve yargılarından çekinmek gibi kaygılar sebebiyle de sağlık hizmetinden yararlanamadıkları görülmüştür. Konu çocukları olduğunda anneler, annelik görevlerinin yargılanacağı/eleştirileceği korkusuyla pek çok soruyu dile getiremediklerini itiraf etmişlerdir. Zamanla toplumun sağlık ve utanma üstüne tabularını yıktığını düşünen çoğu katılımcı, yine de bireysel utangaçlıkların devam ettiğini dile getirmiştir. Kadın-doğum için özel-devlet fark etmeksizin doktorun tavrının memnuniyette asıl faktör olduğunu tüm katılımcılar belirtmiştir.

2008 yılında yapılan insanların sağlık hizmetine başvuru ve yardım arama davranışının faktörlerini inceleyen niteliksel bir araştırmada, bireylerin sağlık hizmetlerine aktif katılımını arttıran; semptom ve sonuçlarla ilgili daha fazla bilgi sahibi olmaya teşvik eden müdahalelerin, uygun yardım arama ve hizmet kullanımını kolaylaştıracağ1 bulunmuştur. ${ }^{19}$ Bizim araştırmamızda da benzer şekilde önyarg1 ve utanma nedenli karşılanamayan hizmetlere karşı doktorların bilgi vermesinin ve personel tavrının önemi vurgulanmıştır.

Amerika'da akıl sağlığı hizmeti alan katılımcılarla yapılan niteliksel bir araştırmada sağlık davranışı teşvikleri dört ana temada tanımlanmıştır: (a) güçlendirme, öz değer ve kişisel gelişim faktörleri; (b) sosyal destek ihtiyac1; (c) değişim nedenleri, hedef belirleme ve zamanlama gibi pragmatik / motivasyonel görüşme hususları; ve (d) ulaşılabilirlik. Bizim araştırmamızda da hizmet alımına yönelik alt yap1 eksiklikleri ve ulaşılabilirliğin önemli olduğu görülmüştür. ${ }^{22}$

Bizim araştırmamızda birçok katılımcı şikâyetleri "basit bir şey" ise sağlı ocağı veya devlet hastanesine gideceklerini; ama daha önemliyse hem daha iyi bakılacağı ve nazik olunacağı, hem oradaki doktorların daha bilgili olduğu düşüncesi yaygın olduğu için özel hastane tercih edeceklerini belirtmişlerdir. Kayseri İli’nde "15-49 Yaş Grubu Kadınların Sağlık Ocağından Yararlanma Durumu ve Beklentileri” adlı çalışmada araştırma grubunun hastalık halinde ilk tercih edeceği sağlık kuruluşları: Sağlık ocağı ve Devlet hastanesi olarak sıralanmıştır. Bu çalışmanın hali hazırda Sağlık Ocağına başvurmuş kadınlar üzerinde yapılmış olmasına rağmen sağlık ocağına gelmeyi tercih edeceklerin çalışmaya katılanların ancak yarısı kadar olması bizim sonuçlarımıza benzer bir sağlık davranışı olduğunu düşündürmüştür. ${ }^{23}$

Bizim çalışmamızda Aile Sağlığ Merkezleri'nde sunulan hizmetlerle ilgili olumlu olarak “...bizim orada sağllk ocaklarında daha iyi bakım oluyor...” ifadesi 
yanında olumsuz ifadeler de sıralanmıştır. Bu olumsuz ifadeler arasında; Aile Sağlık Merkezi'ne duyulan güvensizlik, Aile Sağlık Merkezleri'ndeki teknik donanım azlığı, hasta yoğunluğu, aile hekiminin bilgisiz olduğu düşüncesi, doktorun ve personelin kaba tavrı vurgulanmıştır. Ağdemir'in 2012'deki çalışmasında Aile Hekimliği uygulamasında hastaların genel memnuniyet oranlarının yüksek çıktığı görülmüştür. ${ }^{24}$ Düzce'de yapılan bir araştırmada ise Aile hekimliği uygulamasında hekimlerinin davranışlarının ve vermiş oldukları hizmetlerin, hasta memnuniyetini olumlu etkilediği ve aile hekimini değiştirmek istemeyen ve başkalarına tavsiye eden hastaların memnuniyetlerinin daha yüksek çıktığı saptanmıştır. 2015 yılında yapılan bu araştırmaya katılanlardan aile hekimliği uygulamasını olumlu algılayanların, almış oldukları hizmetleri daha kaliteli algıladıklarını da ortaya koymuştur. Dolayısıyla hastaların aile hekimliği uygulaması ile ilgili algıları olumlu olarak değiştirilebildiğinde hizmet kalitesi algıları ve memnuniyet düzeyleri de yükseltilmiş olacaktır. 25

\section{SONUÇ}

Bireylerin sağlık hizmetlerinden yararlanmasını, sosyokültürel özellikleri ile sağlık hizmetlerinin sunum şekli ve sağlık çalışanlarının tutumu ile ilgili beklentileri etkilemektedir. Dolayısıyla sağlık çalışanlarının mesleki eğitimleri planlanırken başvuranların sağlık algısını etkileyen sosyokültürel özelliklerin dikkate alınması, iletişim becerilerini geliştiren ve olumlu tutum gelişimini sağlayan öğrenme yöntemlerinin kullanılması düşünülmelidir. Ayrıca sağlık hizmetlerinin örgütlenmesinde, başvuranların sağlı hizmetlerinden yararlanmasını etkileyen nedenlerin dikkate alınması karşılanmayan gereksinimlerin giderilmesi açısından etkili olacaktır.

Toplumsal faktörlerin sağlık ve hastalık olguları üzerindeki nedensel rolü, etkileme sınırları ve dereceleri her zaman açık olmamakla birlikte, günümüzde bu faktörler ile sağlık ve hastalık olguları arasında karşılıklı bir etkileşim olduğu kabul edilmektedir. İster gelişmiş ister gelişmekte olsun, tüm toplumlarda bu etkileşime ait sorunlar farklı düzeylerde görülmeye devam etmektedir. Toplum sağlığının korunması, sürdürülmesi, yükseltilmesi ve sağl1kta eşitsizliklerin giderilmesinde bu etkileşimin ortaya konulması son derece önemlidir.
Bireylerin sağlı hizmetlerinden yararlanmasını, sosyokültürel özellikleri, sağlık hizmetlerinin sunum şekli ve sağlık çalışanlarından beklentileri etkilemektedir. Özellikle sağlık çalışanlarının mesleki eğitimleri, sağlık hizmeti almak için başvuranların sosyokültürel faktörlerini ve beklentilerini de dikkate alan bir bakış açısıyla planlanmalıdır. Araştırmanın en sık tekrarlanan ifadeleri, hastaların personel ve doktor tarafından çok kez küçümsendiği ve bu durumdan çok şikâyetçi olduklardır. $\mathrm{Bu}$ konuda iletişim becerileri ve tutum gelişimini sağlayacak öğrenme stratejilerinin kullanılması, mezuniyet öncesi tıp eğitiminden başlayarak yürütülmesi düşünülmelidir. Sağlık hizmetlerinin örgütlenmesinde sağlı hizmetlerinden yararlanmayı etkileyen faktörlerin dikkate alınması, kadın sağlığı konusunda karşılanmayan gereksinimin giderilmesi anlamında çok etkili olacaktır.

\section{KAYNAKLAR}

1. UN Department of Public Information, Platform for Action and the Beijing Declaration, New York, paragraf 89. 1996.

2. Shaikh BT, Hatcher J. Health Seeking Behaviour and Health Service Utilization in Pakistan: Challenging the Policy Makers. Journal of Public Health. 2005; 27 (1): 49-54.

3. Mosadeghrad AM, "Patient choice of a hospital: implications for health policy and management", International Journal of Health Care Quality Assurance, 2014; $27: 2$ : 152 - 164.

4. Kartal A, Özsoy SA. 15 Yaş ve Üzeri Kadın ve Erkeklerde Algılanan Sağlık Durumunun Değerlendirilmesi. Sağlık ve Toplum, 2004; 14 (1) : 29-36.

5. Allensworth, D. D, Fertman, C. I. (Eds.). Sağlığı geliştirme programları: Teoriden pratiğe. Sağlık Bakanlığı. 2012.

6. Gözüm S, Çapık C. Sağlık Davranışlarının Geliştirilmesinde Bir Rehber: Sağlık İnanç Modeli. DEUHYO ED 2014;7(3): 230-237.

7. Erkoç Y, Çom S, Keskinkılıç B, Karakaya K, Özcebe H, Çalışkan D, et al. T.C. Sağlığın Geliştirilmesi Eğitimi. Deniz matbaacılık. Ankara; 2011. p. 21-23. 
8. İlçioğlu K, Keser N, Çınar N. Ülkemizde Kadın Sağlığ 1 ve Etkileyen Faktörler. Journal of Human Rhythm. 2017;3(3):112-119.

9. Akın A, Esin Ç, Çelik K. Kadının Sağlık Hakk1 ve Dünya Sağlık Örgütü'nün Avrupa'da Kadın Sağlığının İyileştirilmesine Yönelik Stratejik Eylem Planı, 2004, s. 26

10. Altıparmak, S, Koca, AK. 15-49 Yaş Grubu Kadınlarda Sağlığı Geliştirme Davranışları ve Etkileyen Faktörler. TAF Preventive Medicine Bulletin, 2009; 8(5): 421-426.

11. Bilgili N, Ayaz S. Kadınların Sağlığı Geliştirme Davranışları ve Etkileyen Faktörler. TAF Preventive Medicine Bulletin, 2009; 8(6).

12. Bilgili N, Ayaz S. Kadınların Sağlığ Geliştirme Davranışları ve Etkileyen Faktörler. TAF Preventive Medicine Bulletin, 2009; 8 (6): 497-502.

13. Türkiye Halk Genel Müdürlüğü. Türkiye'de Aile Hekimliği. 2015. https://hsgm.saglik.gov.tr/tr/ailehekimligi/1394t\%C3\%BCrkiye-de-aile-hekimli\%C4\%9Fi.html Son erişim tarihi: 05.03.2019

14. Yılmaz M, Mayda A, Yüksel C, Bolu F, Seval O, Bayındır K, Gençer H, Soydan B, Sarı A, Sevinçer S, Paksoy F, Öztürk Ş, Palabıyık E, Toçoğlu H. "Bir Aile Hekimliği Merkezi'ne Başvuran Hastalara Konulan Tanılar". Düzce Üniversitesi Sağlık Bilimleri Enstitüsü Dergisi 2 (2013): 7-13.

15. Altay B. 15-49 Yaş Grubu Kadınların Sağlık Ocağ1 Hizmetlerini Bilme Ve Kullanma Durumları İle Etkileyen Faktörlerin İncelenmesi. Atatürk Üniversitesi Hemşirelik Yüksekokulu Dergisi, 2009; 12: 2: 66-76.

16. Tekin A, Özkul M. Sağlık-Hastalık Olgusu Ve Toplumsal Kökenleri (Burdur Örneği), Süleyman Demirel Üniversitesi Sosyoloji Ana Bilim dalı. YL Tezi Kitaplaştırılmış.2007 http://tez.sdu.edu.tr/Tezler/TS00573.pdf

Son erişim tarihi: 03.03.2019

17. Rizk, EED et al. Determinants of women's choice of their obstetrician and gynecologist provider in the UAE. Acta obstetricia et gynecologica Scandinavica, 2005, 84(1): 48-53.
18. Pınar G, Pınar T. Yeni doğum yapmış kadınların empatik iletişim beklentilerinin ebe/hemşireler tarafindan karşılanma durumu. Tıp Araştırmaları Dergisi. Ankara: 2009:7 (3) :132- 140.

19. Zerenler M, Öğüt A. Sağlık Sektöründe Algilanan Hizmet Kalitesi ve Hastane Tercih Nedenleri araştırması: Konya Örneği. Selçuk Üniversitesi Sosyal Bilimler Enstitüsü Dergisi, 2007, 18: 501-519.

20. Arshad AS, et al. Measuring patient satisfaction: A cross sectional study to improve quality of care at a tertiary care hospital. Health line, 2012; 3(1): 43-6.

21. Seviğ Ü, Kızılırmak A. Bir Sağlık Ocağına Kayıtlı 40-59 Yaş Grubu Kadınların Menopoz Yakınmaları ve Sağlık Kuruluşlarından Yararlanma Durumları. Sted 2011;20(4):149-54.

22. Graham, C, Rollings, C, de Leeuw, S, Anderson, L, Griffiths, B, Long, N. A Qualitative Study Exploring Facilitators for Improved Health Behaviors and Health Behavior Programs: Mental Health Service Users' Perspectives. The Scientific World Journal, 2014, 1-7.

23. Naçar M, Çetinkaya F, Öztürk Y. Kayseri İli'nde 15-49 Yaş Grubu Kadınların Sağlık Ocağından Yararlanma Durumu ve Beklentileri. Sted 2004;13( 3):106-109.

24. Ağdemir, H. Sağlık Sektöründe Aile Hekimliği Yeri ve Önemi İle Hizmetten Yararlananların ve Hizmet Sunanların Memnuniyet Durumu Konusunda Bir Araştırma. Çağ Üniversitesi Sosyal Bilimleri Enstitüsü Yüksek Lisans Tezi, Mersin. 2012

25. Yalman F, Bayat $\mathrm{M}$, Çatı $\mathrm{K}$. Aile hekimliği uygulamasının hekimlerin sunmuş olduğu hizmetlerin kalitesine etkisi: Düzce örneği. Abant İzzet Baysal Üniversitesi Sosyal Bilimler Enstitüsü Dergisi, 2015, Cilt:15, Yıl:15, Sayı:1, 15: 23-50. 